\title{
Penyusunan Indeks Tingkat Pelayanan Sistem Pengelolaan Sampah Kota
}

\author{
ABDUL ASIS RUMAKAT ${ }^{1}$, IWAN JUWANA ${ }^{1}$, SITI AINUN ${ }^{1}$
}

1. Jurusan Teknik Lingkungan, Fakultas Teknik Sipil dan Perencanaan, Institut Teknologi Nasional, Bandung

Email : asis.rumakat17@gmail.com

\begin{abstract}
ABSTRAK
Data PD. Kebersihan Kota Bandung, menunjukkan persentase tingkat pelayanan sampah pada tahun 2017 sebesar 98,14\%. Namun pada kenyataannya, masih banyak ditemukan tumpukan sampah di beberapa tempat yang bukan peruntukannya, hal ini menunjukkan angka tersebut belum dapat mewakili pelayanan sampah secara keseluruhan. Penelitian ini bertujuan untuk menyusun indeks yang digunakan untuk menilai kinerja pelayanan sampah kota. Indeks ini disusun dengan cara mengidentifikasi komponen, indikator dan subindikator, menentukan kriteria penilaian, melakukan pembobotan, melakukan penggabungan serta menyusun interpretasi indeks. Terdapat 5 komponen, 26 indikator dan 21 sub-indikator yang teridentifikasi. Pembobotan dilakukan dengan pemberian nilai berbeda pada komponen, indikator dan sub-indikator dengan metode aritmatik. Interpretasi indeks dibuat kedalam 5 kategori dengan skala 0-100. Dari hasil penyusunan indeks ini, selanjutnya akan digunakan untuk menilai tingkat pelayanan persampahan di Kota Bandung.
\end{abstract}

Kata kunci : tingkat pelayanan, komponen, indikator, sub-indikator.

\begin{abstract}
According to the data from PD Kebersihan Kota Bandung, in 2017 the percentage of the performance level of solid waste is $98.14 \%$. However, it is visible that a large amount of solid waste dumped directly to the environment. This indicates that the existing service level performance value is unable to represent the overall solid waste service. Thus, this study aims to develop a solid waste service level index. This study was undertaken by selecting components, indicators and sub-indicators, determining the weights for the components, indicators and sub-indicators, as well as defining the aggregation and interpretation of the final index. Thorough this study, 5 components, 26 indicators and 21 sub-indicators were identified. The chosen weights for the index was the different weighting. Aggregation index using arithmetic method with the interpretation of the final index will be based on 5 categories of 0-100 scale.
\end{abstract}

Keywords : service level, component, indicator, sub-indicator. 


\section{PENDAhUlUAN}

Saat ini, tingkat pelayanan sampah Kota Bandung ditentukan berdasarkan banyaknya timbulan sampah yang terangkut ke Tempat Pemrosesan Akhir Sampah (TPAS). Menurut data PD. Kebersihan Kota Bandung,pada tahun 2017 persentase tingkat pelayanan sampahsebesar $98,14 \%$. Namun, nilai tersebut belum menunjukkan pelayanan sampah secara keseluruhan, salah satunya ditunjukkan denganmasih banyaknya tumpukan sampah dibeberapa lokasi Tempat Penampungan Sementara (TPS) atau TPS liar, bantaran sungai dan selokan(Nugraha, 2017).

Selain itu,terdapatupaya lain yang dianggap dapat mewakili tingkat pelayanan sampah kota adalahpenilaian Adipura. Namun, penilaian ini tidak hanya difokuskan pada aspek persampahan, melainkan juga pada aspek pemanfaatan ruang terbuka hijau, upaya pemantauan kualitas air bersih dan kualitas udara(Peraturan Menteri Lingkungan Hidup Republik Indonesia No. 6, 2014).Tidak fokusnya peraturan menteri ini pada upaya penilaian pengelolaan sampah mengakibatkan peraturan ini belum dapat digunakan sebagai salah satu alat ukur untuk menilai sistem pengelolaan sampah kota secara menyeluruh.

Berdasarkan hal-hal tersebut diatas menunjukkan bahwa alat ukur penilaian pelayanan sampah yang ada saat ini belum dapat menggambarkan pelayanan sistem pengelolaan sampah di suatu kota, sehingga perlu dibuat sebuah kriteria penentuan tingkat pelayanan sampah yang mudah digunakan dan terintegrasi terhadap semua aspek persampahan. Adanya kriteria ini akan mempermudah pelaksanaan pemantauan dan evaluasi sistem pengelolaan sampah kota, karena telah mempertimbangkan faktor penanganan dan pengurangan sampah. Kriteria yang dimaksudkan adalah dengan penyusunan sebuah indeks tingkat pelayanan sampah kota. Indeks ini dapat digunakan sebagai tools atau alat untuk memantau dan mengevaluasi sistem pengelolaan sampah kota.

Maksud dari penelitian ini adalah menyusun indeks tingkat pelayanan sampah kota dengan tujuan mengidentifikasi komponen, indikator dan sub-indikator, melakukan pembobotan, menentukan penggabungan dan interpretasi indeks.

\section{METODOLOGI}

\subsection{Identifikasi Komponen, Indikator,dan Sub-Indikator serta Penentuan Kriteria Penilaian}

Proses identifikasi komponen, indikator, dan sub-indikator serta penentuan kriteria penilaian dapat dilihat pada Gambar 1.

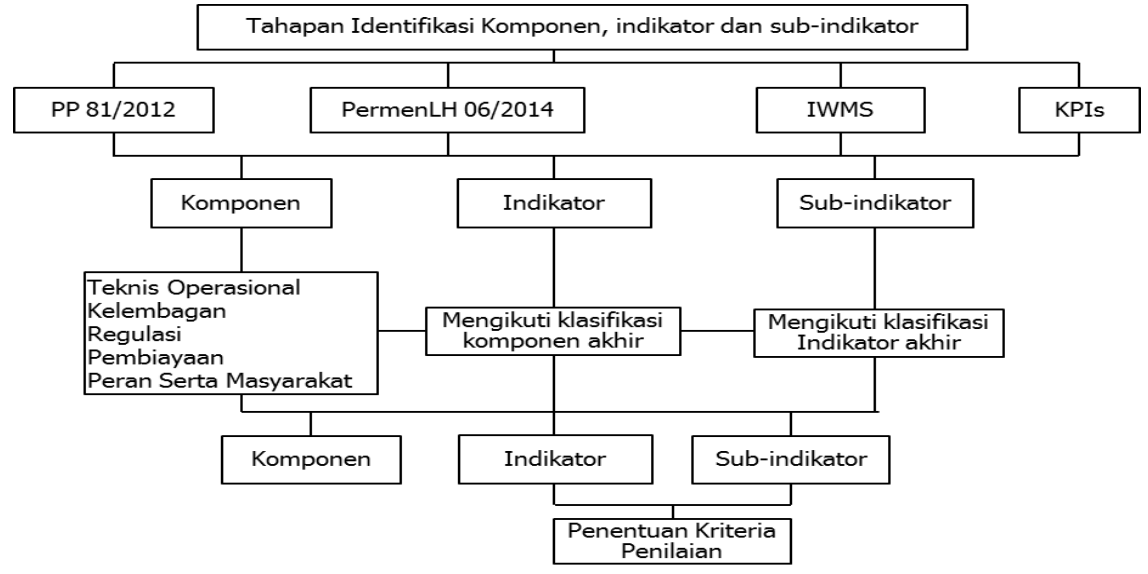

Gambar 1.Tahapan Identifikasi Komponen, Indikator dan Sub-Indikator serta Penentuan Kriteria Penilaian 
Berdasarkan Gambar 1.proses identifikasi komponen, indikator dan sub-indikatordibagi kedalam dua tahap. Tahap pertama adalah melakukan identifikasi dari empat literatur, yaitu Peraturan Pemerintah No. 81 Tahun 2012 tentang Pengelolaan Sampah Rumah Tangga dan Sampah Sejenis Rumah Tangga, Peraturan Menteri Lingkungan Hidup No. 6 Tahun 2014 tentang Pedoman Pelaksanaan Program Adipura, Integrated Waste Management Scoreboard (IWMS)(UNEP, 2005), dan key performance index (KPIs)for solid waste management(Elsadig dkk., 2016).Dari proses identifikasi ini akan menghasilkan sebuah kerangka awal yang terdiri dari komponen, indikator dan sub-indikator.

Tahap kedua adalah melakukan klasifikasi komponen yang telah teridentifikasi kedalam lima komponen yang direncanakan yaitu komponen teknis operasional, kelembagaan, regulasi, pembiayaan dan peran serta masyarakat.Proses klasifikasi ini dilakukan dengan mempertimbangkan kesamaan bahasan secara teoritis dan pembahasan pada masingmasing literatur. Setelah komponen yang direncanakan terbentuk, selanjutnya dilakukanklasifikasi indikator dan sub-indikator kedalam lima komponen tersebut disesuaikan dengan cakupan bahasan masing-masing komponen, sehingga akan menghasilkan sebuah kerangka akhir yang terdiri dari komponen, indikator dan sub-indikator akhir.Langkah selanjutnya setelah kerangka akhir terbentuk adalah penentuan kriteria penilaian.Penentuan kriteria ini dilakukan dengan menganalisis semua indikator dan sub-indikator yang telah terseleksi, sehingga semua indikator dan sub-indikator dapat dinilai secara maksimal.

\subsection{Pembobotan}

Pembobotan dilakukan untuk menentukan nilai bobot dari komponen, indikator dan subindikator. Pembobotan yang dilakukan pada indeks tingkat pelayanan ini adalah dengan pemberian nilai bobot yang berbeda pada komponen, indikator dan sub-indikator. Hal ini dikarenakan penentuan nilai bobot perlu mempertimbangkan kriteria dan perbedaan pendapat, sehingga menyebabkan pemberian nilai bobot pada komponen, indikator dan sub-indikator berbeda antara satu dengan lainnya (Wang dan Lee, 2009). Menurut Fatimah (2016)penentuan nilai sebuah bobot berkisar pada rentang $0-1$ atau $0 \%-100 \%$. Proses penentuan nilai bobot dimulai dari penentuan bobot komponen, indikator dan sub-indikator.

\subsection{Agregasi atau Penggabungan Indeks}

Agregasi atau penggabungan indeks dilakukan dengan cara menggabungkan komponen, indikator dan sub-indikator.Sebagai contoh pada Gambar 2.diagram alir agregasi indeks.

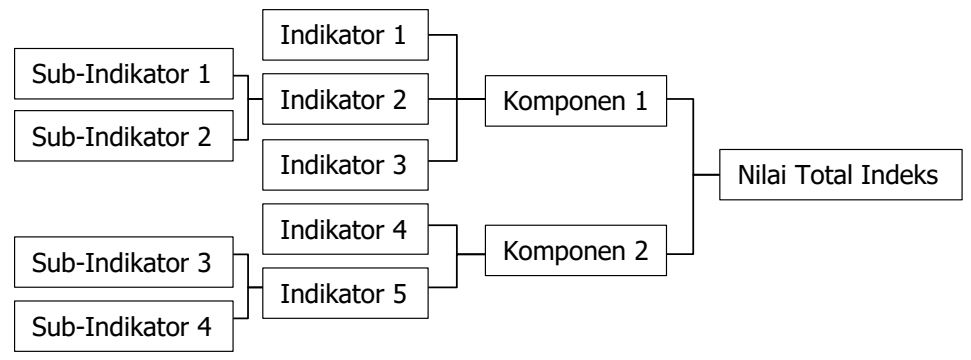

\section{Gambar 2. Proses Agregasi Indeks}

Agregasiini dilakukan untuk mengetahui indeks tingkat pelayanan yang direncanakan.Untuk menentukannya dapat dilakukan dengan menggunakan metode artimatik dan metode geometri.Kedua metode ini dapat digunakan sebagai rangkuman dari pembobotan pada nilai sub-indeks (Nardo dkk., 2005). Persamaan aritmatik yang digunakan untuk prosesagregasi yaitu :

$$
I=\sum_{i=1}^{N} w i S i
$$


dimana $I$ merupakan nilai penggabungan indeks, $\mathrm{N}$ adalah jumlah indikator yang digabungkan, $s_{i}$ adalah sub-indeks untuk indikator i dan $w_{i}$ adalah nilai pembobotan dari indikator i.Selain persamaan aritmatik diatas dapat juga menggunakan persamaan geometrik berikut.

$$
I=\prod_{i=1}^{N} S i^{W i}
$$

Keterangan simbol pada persamaan ini sama seperti keterangan simbol pada persamaan aritmatik sebelumnya.

Perbedaan antara metode aritmatik dan metode geometri adalah nilai agregasi yang dihasilkan tidak sama dari masing-masing komponen/indikator/sub-indikator jikamemiliki nilai sub-indeks yang signifikan berbeda. Sebagai contoh indikator 1 dan 2 memiliki nilai subindeks sama yaitu 30 dan pada kasus lain indikator 1 memiliki nilai sub-indeks 0 dan indikator 2 memiliki nilai sub-indeks 60 dengan teknik pemberian nilai bobot yang seimbang. Kedua kasus ini jika menggunakan metode aritmatika akanmenghasilkan nilai agregasi yang sama yaitu 30 pada kedua kasus. Sedangkan jika menggunakan metode geometrik, maka untuk kasus pertama memiliki nilai agregasi sebesar 30 dan 0 untuk kasus kedua.Berdasarkan hal tersebut, maka metode agregasi indeks yang digunakan pada penelitian ini adalah metode aritmatik karena tidak terpengaruh oleh perbedaan nilai yang signifikan.

\subsection{Interpretasi Indeks}

Interpretasi indeks diperlukan untuk menentukan nilai kesiapan dari indeks yang telah ditentukan. Sebagai contoh pada kasus Penyusunan Indikator Bank Sampah Skala Kota yang menginterpretasikan kedalam dua kategori. Hasilnya menunjukkan bahwa jika nilai indeks bank sampah yang didapatkan berada pada rentang nilai $0-<55,20$ maka bank sampah tersebut belum siap untuk dikembangkan. Namun, jika memiliki rentang nilai antara $>55,20-$ 100 maka bank sampah tersebut telah siap untuk dilakukan pengembangan (Dewi, 2017). Selain itu, terdapat beberapa indeks lain yang melakukan proses interperatasi sejenis, namun terbagi dalam beberapa kategori, diantaranya ada yang menggunakan lima kategori seperti Canadian Water Quality Index (CWQI) (Saffran dkk., 2001) dan National Sanitation Foundation Water Quality Index (SFWQI) (Brown dkk., 1970)serta ada juga yang menggunakan empat kategori seperti West Java Water Sustainable Index (WJWSI) (Juwana, 2012).

\section{HASIL DAN PEMBAHASAN}

\subsection{Identifikasi Komponen, Indikator dan Sub-Indikator}

Proses identifikasi komponen, indikator dan sub-indikator mangacu pada Peraturan Pemerintah No. 81 Tahun 2012 tentang Pengelolaan Sampah Rumah Tangga dan Sampah Sejenis Rumah Tangga, Peraturan Menteri Lingkungan Hidup No. 6 Tahun 2014 tentang Pedoman Pelaksanaan Program Adipura, Integrated Waste Management Scoreboard (IWMS), dan key performance index (KPIs) for solid waste management. Proses penentuannya dilakukan dengan melihat struktur pembahasan dari masing-masing literatur. Sebagai contoh identifikasi komponen, indikator dan sub-indikator dari Peraturan Pemerintah No. 81 Tahun 2012 dan Peraturan Menteri Lingkungan Hidup No. 6 Tahun 2014. Jika dilihat dari struktur peraturannya maka kedua peraturan initerdiri dari judul bab, ayat dan pasal. Ketiga faktor tersebut kemudian akan digunakan untuk menganalisis komponen, indikator dan subindikator. Untuk mempermudah pembahasan ini, pada Gambar 3.dapat dilihat diagram alir penentuan komponen, indikator dan sub-indikator dari Peraturan Pemerintah No. 81 Tahun 2012 dan Peraturan Menteri Lingkungan Hidup No. 6 Tahun 2014. 


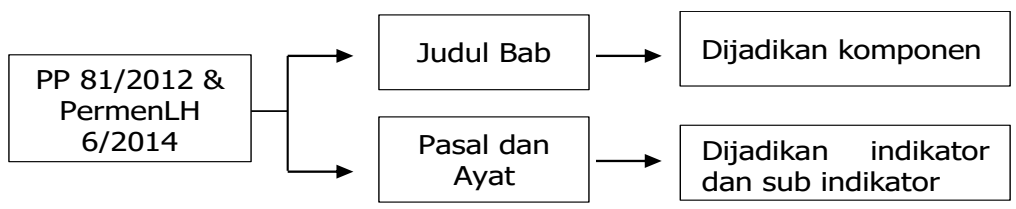

Gambar 3.Diagram Alir Penentuan Komponen, Indikator dan Sub-Indikator

Judul bab dari peraturan dijadikan sebagai komponen karena pada dasarnya judul bab memiliki cakupan informasi yang lebih luas dan lebih umum dibandingkan dengan pasal atau ayat. Pemberian nama komponen dalam penyusunan indeks diharapkan dapat mewakili beberapa indikator dan sub-indikator yang memiliki karakteristik sejenis. Namun dapat pula dijadikan sebagai sebuah indikator apabila penentuan nama komponen sebelumnya lebih umum untuk mewakili indikator yang telah ada. Ayat dari pasal pada peraturan ini dapat langsung dijadikan sebagai sebuah indikator, dimana penentuannya dilakukan secara langsung. Hal ini dikarenakan ayat dari pasal pada peraturan ini merupakan penjelasan lebih rinci dari judul bab yang dibahas. Selain itu, dapat pula dijadikan sebagai sub-indikator apabila indikator yang telah ditentukan masih bersifat umum, sehingga perlu ada penjelasan secara lanjut.

\subsubsection{Identifikasi Komponen}

Pemilihan komponen dalam Penyusunan Indeks Tingkat Pelayanan Sampah Kota ini mengacu pada empat (4) referensi yang digunakan sebelumnya. Dalam Peraturan Menteri Pekerjaan Umum No. 3 tahun 2013 tentang Penyelenggaraan Prasarana dan Sarana Persampahan dalam Penanganan Sampah Rumah Tangga dan Sampah Sejenis Sampah Rumah Tangga disebutkan pada pasal 5 ayat 2 point c terdapat 5 aspek terkait pengelolaan persampahan diantaranya aspek teknis operasional, aspek kelembagaan, aspek pengaturan (regulasi, hukum), aspek pembiayaan dan aspek peran serta masyarakat. Kelima aspek persampahan tersebut akan digunakan sebagai komponen dalam penyusunan indeks tingkat pelayanan sampah kota. Hal ini dikarenakan lima aspek tersebut dalam penerapannya mudah untuk dilaksanakan dan telah mewakili faktor penanganan serta pengurangan sampah.

\subsubsection{Identifikasi Indikator}

Langkah selanjutnya setelah penentuan komponen adalah identifikasi indikator kedalam limakomponen tersebut dengan mengacu pada bahasan masing-masing komponen. Sebagai contoh, penentuan indikator yang masuk kedalam komponen teknis operasional dari Peraturan Menteri Lingkungan Hidup No. 6 Tahun 2014. Komponen teknis operasional membahas terkait dengan pembatasan timbulan sampah, pendaurulangan sampah, pemanfaatan kembali sampah, pemilahan, pengumpulan, pengangkutan dan pengolahan sampah serta tempat pemrosesan akhir sampah(Peraturan Menteri Pekerjaan Umum No. 3, 2013). Berdasarkan uraian tersebut, sehingga yang masuk kedalam komponen teknis operasional dari peraturan ini adalah indikator pengolahan sampah, 3R (reuse, reduce, recycle) dan pembuangan akhir. Hal ini dikarenakan ketiga indikator ini membahas tentang pengolahan, pemanfaatan kembali dan pembuangan sampah. Cara mangklasifikasikan indikator ini kedalam komponen teknis operasional adalah dengan melihat dan mengidentifikasi kesamaan hal yang dibahas. Penentuan yang sama dilakukan juga pada Peraturan Pemerintah No. 81 Tahun 2012, Integrated Waste Management Scoreboard (IWMS), dan key performance index (KPIs) for solid waste management. Berdasarkan uraian tersebut, pada Tabel 1.dapat dilihat indikator yang masuk kedalam komponen teknis operasional. 
Tabel 1. Indikator dari Komponen Teknis Operasional

\begin{tabular}{lll}
\hline \multicolumn{1}{c}{ Komponen } & \multicolumn{1}{c}{ Indikator Awal } & \multicolumn{1}{c}{ Indikator Gabungan } \\
\hline Teknis Operasional & Penanganan dan Pengurangan Sampah & Pewadahan \\
\hline Teknis Operasional & Pengolahan Sampah & Pengumpulan sampah \\
\hline Teknis Operasional & 3R (reuse, reduce, recycle) & Pengangkutan \\
\hline Teknis Operasional & Pembuangan Akhir & Tempat Pembuangan Akhir \\
\hline Teknis Operasional & Penyimpanan dan Pengumpulan & Upaya minimasi sampah \\
\hline Teknis Operasional & Pengangkutan & \\
\hline Teknis Operasional & Recycle & \\
\hline Teknis Operasional & Akses & \\
\hline Teknis Operasional & Tempat Pembuangan Akhir & \\
\hline Teknis Operasional & Pengumpulan dan pengangkutan & \\
\hline Teknis Operasional & Frekuensi pengumpulan dan pengangkutan &
\end{tabular}

Berdasarkan Tabel 1. terdapat beberapa indikator awal yang memilki kesamaan antara satu indikator dengan indikator lainnya sehingga perlu dilakukan penggabungan indikator. Proses penggabungan ini dilakukan dengan mengidentifikasi indikator yang membahas hal yang sama atau sejenis. Dalam penentuan indikator memungkinkan terjadiperubahan nama pada indikator, hal ini dilakukan agar indikator yang baru dapat mewakili beberapa indikator yang digabung. Sebagai contoh untuk indikator 3R (reuse, reduce, recycle) dan pengolahan sampah dari PermenLH 6 tahun 2014 dan recycle dari IWMS membahas hal yang sama yaitu terkait upaya minimasi sampah, sehingga indikator tersebut masuk kedalam satu bahasan yang sama. Kesamaan bahasan tersebut menyebabkan perlu dilakukan pergantian nama indikator agar dapat mewakili ketiga indikator sebelumnya. Berdasarkan hal tersebut, makanama indikator terbarunya adalah upaya minimasi sampah. Nama indikator ini dipilih karena telah mewakili pengolahan, reuse, reduce dan recycle.

Proses yang identifikasi indikator yang sama dilakukan juga pada komponen kelembagaan, regulasi, pembiayaan, dan peran serta masyarakat, sehingga pada Tabel 2. dapat dilihat rekapitulasi komponen dan indikator terbaru yang telah terseleksi.

Tabel 2. Rekapitulasi Komponen dan Indikator Komponen Indikator

\begin{tabular}{|c|c|}
\hline Komponen & Indikator \\
\hline \multirow{3}{*}{ Regulasi } & Isi Peraturan \\
\hline & Akses Data Peraturan \\
\hline & Kebijakan Hukum \\
\hline \multirow{3}{*}{ Pembiayaan } & Biaya Kompensasi dampak di TPA \\
\hline & Biaya pengeluaran pengelolaan sampah \\
\hline & Biaya penunjang kesehatan tenaga kerja \\
\hline \multirow{5}{*}{ Teknis Operasional } & Pewadahan \\
\hline & Pengumpulan sampah \\
\hline & Pengangkutan \\
\hline & Tempat Pembuangan Akhir \\
\hline & Upaya minimasi sampah \\
\hline \multirow{9}{*}{ Kelembagaan } & Pemantauan dan Pengawasan \\
\hline & Kebijakan dan strategi pengelolaan sampah \\
\hline & Kebersihan Kota \\
\hline & Penyediaan Armada Angkutan \\
\hline & Penelitian terkait sampah \\
\hline & Program pengelolaan sampah kota \\
\hline & sanitary landfill \\
\hline & TPS B3 medis \\
\hline & Pembangunan TPS dan TPST \\
\hline
\end{tabular}


Tabel 2. Rekapitulasi Komponen dan Indikator Komponen Indikator

\begin{tabular}{ll}
\multicolumn{1}{c}{ Komponen } & \multicolumn{1}{c}{ Indikator } \\
\hline & Peningkatan sistem pengangkutan \\
\cline { 2 - 2 } Penyediaan Informasi sampah \\
\hline \multirow{3}{*}{ Peran Serta Masyarakat } & Penyelenggaraan pengelolaan sampah \\
\cline { 2 - 2 } & Kesadaran masyarakat \\
\cline { 2 - 2 } & Partisipasi komunitas \\
\hline
\end{tabular}

Sumber : Hasil Analisis, 2018

\subsubsection{Identifikasi Sub-Indikator}

Penyusunan sub-indikator mengacu pada indikator akhir yang teridentifikasi dari masingmasing komponen. Dalam proses penyusunannya,semua indikator yang teridentifikasi akan memiliki sub-indikator masing-masing.Selain itu, terdapat beberapa indikator yang tidak memiliki sub-indikator. Hal ini dikarenakan indikator tersebut tidak mengalami pembahasan rinci lebih lanjut. Berdasarkan uraian tersebut maka setiap komponen akan memiliki indikator dan sub-indikator tersendiri, sehingga pembahasan penentuan sub-indikator dibahas berdasarkan masing-masing komponen yang digunakan dalam menilai tingkat pelayanan sistem pengelolaan sampah kota. Sebagai contoh, penentuan sub-indikator untuk komponen teknis operasional. Komponen teknis operasional memiliki 5 (lima) indikator, salah satunya yaitu indikator pengangkutan. Sampah yang dihasilkan oleh suatu kota umumnya diangkut menggunakan alat angkut menuju ke Tempat Pemrosesan Akhir Sampah (TPAS). Selain itu, frekuensi pengangkutan dan akses pengangkutan yang dilakukan juga menjadi pertimbangan dalam indikator pengangkutan ini. Hal ini dikarenakan kedua faktor ini sangat mempengaruhi banyaknya timbulan sampah yang diangkut ke TPAS.

Cara penentuan sub-indikator yang sama dilakukan juga pada indikator pada komponen kelembagaan, regulasi, pembiayaan dan peran serta masyarakat. Pada Tabel 3.dapat dilihat rekapitulasi hasil akhir dari penentuan sub-indikator.

Tabel 3.Rekapitulasi Sub-Indikator

\begin{tabular}{|c|c|c|}
\hline Komponen & Indikator & Sub-Indikator \\
\hline \multirow{3}{*}{ Regulasi } & Isi Peraturan & - \\
\hline & Akses Data Peraturan & - \\
\hline & Kebijakan Hukum & - \\
\hline \multirow{5}{*}{ Pembiayaan } & Biaya Kompensasi dampak di TPA & - \\
\hline & \multirow{3}{*}{$\begin{array}{l}\text { Biaya pengeluaran pengelolaan } \\
\text { sampah }\end{array}$} & Biaya pengangkutan sampah kota \\
\hline & & $\begin{array}{l}\text { Biaya fasilitas pengumpulan dan } \\
\text { pengangkutan sampah }\end{array}$ \\
\hline & & Gaji Pegawai kebersihan \\
\hline & $\begin{array}{l}\text { Biaya penunjang kesehatan tenaga } \\
\text { kerja }\end{array}$ & (5 \\
\hline \multirow{8}{*}{ Teknis Operasional } & Pewadahan & - \\
\hline & Pengumpulan sampah & - \\
\hline & \multirow{3}{*}{ Pengangkutan } & Pengangkutan sampah \\
\hline & & Frekuensi pengangkutan \\
\hline & & Akses pengangkutan \\
\hline & \multirow{3}{*}{ Tempat Pembuangan Akhir } & Lahan \\
\hline & & Sampah yang dibuang ke landfill \\
\hline & & $\begin{array}{l}\text { Jarak TPA terhadap pemukiman, badan } \\
\text { air dan pantai }\end{array}$ \\
\hline
\end{tabular}


Tabel 3.Rekapitulasi Sub-Indikator

\begin{tabular}{|c|c|c|}
\hline Komponen & Indikator & Sub-Indikator \\
\hline & & Lamanya masa pakai TPA \\
\hline & & Fasilitas pendukung TPA \\
\hline & & Banyaknya alat angkut TPA \\
\hline & \multirow{2}{*}{ Upaya minimasi sampah } & Pengolahan Sampah \\
\hline & & 3R (reuse, reduce, recycle) \\
\hline \multirow{13}{*}{ Kelembagaan } & Pemantauan dan Pengawasan & - \\
\hline & \multirow{2}{*}{$\begin{array}{l}\text { Kebijakan dan strategi pengelolaan } \\
\text { sampah }\end{array}$} & Target pengurangan sampah Kota \\
\hline & & Target penanganan sampah Kota \\
\hline & Kebersihan Kota & - \\
\hline & Penyediaan Armada Angkutan & - \\
\hline & Penelitian terkait sampah & - \\
\hline & \multirow{2}{*}{ Program pengelolaan sampah kota } & Program bank sampah \\
\hline & & Program 3R \\
\hline & Sanitary landfill & - \\
\hline & TPS B3 medis & - \\
\hline & Pembangunan TPS dan TPST & - \\
\hline & Peningkatan sistem pengangkutan & - \\
\hline & Penyediaan Informasi sampah & - \\
\hline \multirow{5}{*}{$\begin{array}{l}\text { Peran Serta } \\
\text { Masyarakat }\end{array}$} & \multirow{2}{*}{$\begin{array}{l}\text { Penyelenggaraan pengelolaan } \\
\text { sampah }\end{array}$} & Partisipasi dalam pegelolaan sampah \\
\hline & & Kesedian membayar pengelolaan sampah \\
\hline & Kesadaran masyarakat & - \\
\hline & Partisipasi komunitas & - \\
\hline & Pendidikan kesadaran di sekolah & - \\
\hline
\end{tabular}

\section{Sumber : Hasil Analisis, 2018}

\subsection{Penentuan Kriteria Penilaian}

Penyusunan kriteria penilaian digunakan untuk menilai indeks tingkat pelayanan sampah kota. Penentuannya dilakukan dengan menganalisis semua indikator dan sub-indikator yang terseleksi, sehingga indikator dan sub-indikator tersebut dapat dinilai secara maksimal. Kriteria ini dilengkapi juga dengan nilai pada masing-masing kriteria, sehingga semua kriteria yang disusun memiliki penilaian tersendiri.Pada Tabel 5. dapat dilihat contoh kriteria penilaian untuk indikator penyediaan informasi sampah dari komponen kelembagaan.

\section{Tabel 5.Contoh Penentuan Kriteria Penilaian}

\begin{tabular}{clc}
\hline Indikator & \multicolumn{1}{c}{ Kriteria Penilaian } & $\begin{array}{c}\text { Nilai } \\
(\mathbf{\%})\end{array}$ \\
\hline \multirow{2}{*}{$\begin{array}{c}\text { Penyediaan } \\
\text { Informasi } \\
\text { sampah }\end{array}$} & Ada layanan penyedia informasi sampah, mudah diakses dan diperbarui secara berkala & 100 \\
\cline { 2 - 3 } & $\begin{array}{l}\text { Ada layanan penyedia informasi sampah, mudah diakses tapi tidak diperbarui secara } \\
\text { berkala }\end{array}$ & 65 \\
\cline { 2 - 4 } & Ada layanan penyedia informasi sampah namun hanya sedikit yang bisa diakses & 35 \\
\cline { 2 - 4 } & Tidak ada layanan penyedia informasi sampah & 0 \\
\hline
\end{tabular}

Sumber : Hasil Analisis, 2018

\subsection{Pembobotan}

Rentang nilai bobot yang digunakan berkisar antara $0 \%-100 \%$ dengan pemberian nilai berbeda pada masing-masing komponen, indikator dan sub-indikator. Pada Tabel 6.dapat dilihat contoh pemberian bobot pada masing-masing komponen. 
Tabel 6. Pemberian Nilai Bobot Pada Komponen

\begin{tabular}{clc}
\hline No & \multicolumn{1}{c}{ Komponen } & Bobot (\%) \\
\hline 1 & Regulasi & 15 \\
\hline 2 & Pembiayaan & 20 \\
\hline 3 & Teknis Operasional & 22,5 \\
\hline 4 & Kelembagaan & 22,5 \\
\hline 5 & Peran Serta Masyarakat & 20 \\
\hline \multicolumn{2}{l}{ Sumber : Hasil Analisis, 2018 }
\end{tabular}

Penentuan nilai bobot seperti yang dapat dilihat pada Tabel 6. dilakukan dengan mempertimbangkan tingkat kepentingan masing-masing komponen dan jumlah indikator serta sub-indikator pada masing-masing komponen. Komponen teknis operasional dan kelembagaan memiliki nilai bobot yang lebih besar dibandingkan tiga komponen lainnya, karena dianggap lebih penting dengan pertimbangan bahwa kedua komponen ini merupakan komponen yang merencanakan dan melaksanakan pengelolaan sampah kota. Selain itu, jumlah indikator dan sub-indikator pada kedua komponen ini jauh lebih banyak dengan total yaitu 16 untuk komponen teknis operasional dan 12 untuk komponen kelembagaan. Selain itu komponen yang mendapatkan bobot terendah adalah komponen pengaturan atau regulasi. Hal ini dikarenakan komponen tersebut hanya memiliki 3 indikator.

\subsection{Agregasi atau Penggabungan Indeks}

Nilai indeks tingkat pelayanan sampah suatu kota dapat ditentukan dengan cara melakukan penggabungan antara nilai sub-indikator, nilai indikator dan nilai komponen (Juwana, 2012). Penggabungan nilai ini dilakukan agar nilai akhir dari indeks tingkat pelayanan sampah sebuah kota dapat diketahui. Penentuan agregasi indeks ini menggunakan metode aritmatik. Contoh agregasi indeks indeks dapat dilihat pada Tabel 7. dan uraian berikut ini :

Tabel 7. Contoh Agregasi atau Penggabungan Indeks

\begin{tabular}{|c|c|c|c|c|c|c|c|}
\hline \multirow{2}{*}{ K } & \multirow{2}{*}{$\begin{array}{c}\text { Nilai } \\
\text { Maks. K }\end{array}$} & \multirow{2}{*}{ I } & \multirow{2}{*}{$\begin{array}{c}\text { Nilai } \\
\text { Maks. I }\end{array}$} & \multirow{2}{*}{ Kriteria } & \multirow{2}{*}{$\begin{array}{c}\text { Penilaian } \\
(\%)\end{array}$} & \multicolumn{2}{|c|}{ Nilai Total } \\
\hline & & & & & & I & $\mathbf{K}$ \\
\hline \multirow{3}{*}{$\begin{array}{l}\text { Regulasi } \\
(15 \%)\end{array}$} & \multirow{3}{*}{15} & $\begin{array}{c}\text { Isi Peraturan } \\
(34 \%)\end{array}$ & 5.10 & $\begin{array}{l}\text { Mengatur terkait retribusi } \\
\text { dan menetapkan target } \\
\text { pengurangan sampah }\end{array}$ & 100 & 5.1 & \multirow{3}{*}{12.03} \\
\hline & & $\begin{array}{l}\text { Akses Data } \\
\text { Peraturan } \\
(33 \%)\end{array}$ & 4.95 & $\begin{array}{l}\text { Data utama tersedia, } \\
\text { mudah diakses, namun } \\
\text { tidak diperbarui secara } \\
\text { berkala }\end{array}$ & 75 & 3.71 & \\
\hline & & $\begin{array}{l}\text { Kebijakan } \\
\text { Hukum } \\
(33 \%)\end{array}$ & 4.95 & $\begin{array}{l}\text { Ada prosedur penegakan } \\
\text { hukum, didukung SDM } \\
\text { dan keuangan, tapi tidak } \\
\text { diimplementasikan }\end{array}$ & 65 & 3.22 & \\
\hline
\end{tabular}

Keterangan : $K=$ Komponen, $I=$ Indikator

Sumber : Hasil Analisis, 2018

Pada Tabel 7.dilihat bahwa nilai persentasi untuk kriteria penilaian merupakan contoh asumsi nilai yang digunakan untuk melakukan agregasi, sehingga perhitungannya adalah :

Nilai Indikator $\quad=\Sigma$ wiSi

$$
=(100 \% \times 5,10)+(75 \% \times 4,95)+(65 \% \times 4,95)=12,03
$$

Langkah selanjutnya adalah menghitung nilai komponen. Pada tahap ini perhitungan dilakukan dengan cara menjumlahkan semua nilai indikator pada masing-masing komponen terkait. Untuk contoh perhitungannya dapat dilihat pada uraian berikut, yaitu :

Komponen Regulasi $=\Sigma$ Nilai indikator komponen regulasi

$$
\begin{aligned}
& =\text { Indikator (isi peraturan }+ \text { akses data peraturan }+ \text { kebijakan Hukum) } \\
& =12,03
\end{aligned}
$$


Pada akhirnya untuk mendapatkan nilai indeks, maka dilakukan penjumlahan semua nilai komponen. Asumsi bahwa penilaian yang dilakukan untuk 4 komponen lain telah memenuhi nilai maksimum dari masing-masing komponen.

Nilai Total Indeks $=\Sigma$ nilai komponen

$$
\begin{aligned}
& =\text { Komponen (regulasi }+ \text { teknis operasional }+ \text { kelembagaan }+ \\
& \text { pembiayaan }+ \text { peran serta masyarakat) } \\
& =12,03+22,5+22,5+20+20=97,03
\end{aligned}
$$

\subsection{Interpretasi Indeks}

Interpretasi indeks sangat diperlukan untuk memahami sub-indeks danagregasinilai indeks (Juwana, 2012). Pada dasarnya interpretasi indeks untuk sampah belum ditemukan informasi sehingga pendekatan dilakukan dengan menggunakan Canadian Water Quality Index (CWQI)(Saffran dkk., 2001), National Sanitation Foundation Water Quality Index (SFWQI)(Brown dkk., 1970), dan West Java Water Sustainable Index (WJWSI)(Juwana, 2012). Interpertasi dari ketiga indeks ini dapat dilihat pada Tabel 8.

Tabel 8. Interpretasi Indeks dari CWQI, SFWQI dan WJWSI

\begin{tabular}{cclclrl}
\hline \multirow{2}{*}{ No } & \multicolumn{2}{c}{ CWQI } & \multicolumn{2}{c}{ SFWQI } & \multicolumn{2}{c}{ WJWSI } \\
\cline { 2 - 7 } & Nilai & Interpretasi & Nilai & Interpretasi & Nilai & Interpretasi \\
\hline 1 & $95-100$ & Sangat Baik & $90-100$ & Sangat Baik & $75-100$ & Sangat Baik \\
\hline 2 & $80-94$ & Baik & $70-90$ & Baik & $50-<75$ & Baik \\
\hline 3 & $65-79$ & Sedang & $50-70$ & Sedang & $25-<50$ & Cukup Buruk \\
\hline 4 & $45-64$ & Cukup Buruk & $25-50$ & Buruk & $0-<25$ & Buruk \\
\hline 5 & $0-44$ & Buruk & $0-25$ & Sangat Buruk & & \\
\hline
\end{tabular}

Jika dilihat dari Tabel 8. interpretasi dari ketiga indeks ditentukan berdasarkan rentang nilai maksimum. Ketiga indeks ini CWQI, SFWQI dan WJWSI menggunakan skala dari 0-100, jika nilai indikator menunjukkan nilai yang lebih dekat pada angka 100 maka dianggap lebih baik, sedangkan jika nilai indikator yang didapatkan mendekati angka 0 maka dianggap lebih buruk. Pada indeks tingkat pelayanan sampah, interpretasi dilakukan berdasarkan pada 5 kategori. Dengan kategori ini, maka nilai maksimum indeks sebesar 100 dan nilai

\begin{tabular}{|c|c|c|}
\hline No & Nilai & Kinerja \\
\hline 1 & $90-100$ & Sangat Baik \\
\hline 2 & $70-<90$ & Baik \\
\hline 3 & $50-<70$ & Kurang Baik \\
\hline 4 & $25-<50$ & Buruk \\
\hline 5 & $0-<25$ & Sangat Buruk \\
\hline
\end{tabular}
minimumnya adalah 0 . Berdasarkan uraian tersebut, hasil klasifikasi interpretasi indeks dapat dilihat pada Tabel 9.

Sumber : Hasil Analisis, 2017

Penentuan lima kategori interpretasi ini didapatkan dengan cara mengkomparasi 3 (tiga) indeks sebelumnya yaitu CWQI, SFWQI dan WJWSI. Selain itu, pembagian kategori ini dilakukan dengan pertimbangan bahwa dengan lima kategori ini, maka akan lebih rinci untuk menilai tingkat pelayanan sampah yang telah dilaksanakan (Saffran dkk., 2001).

\section{KESIMPULAN}

Penyusunan indeks tingkat pelayanan sistem pengelolaan sampah kota ditentukan menggunakan Peraturan Pemerintah No. 81 Tahun 2012 tentang Pengelolaan Sampah Rumah Tangga dan Sampah Sejenis Rumah Tangga, Peraturan Menteri Lingkungan Hidup No. 6 Tahun 2014 tentang Pedoman Pelaksanaan Program Adipura, Integrated Waste 
Management Scoreboard (IWMS) dan key performance index (KPIs) for solid waste management. Penentuan penilaian ini dibuat dalam bentuk komponen, indikator dan subindikator. Hasil analisis menunjukkan bahwa terdapat 5 komponen 26 indikator dan 21 subindikator yang terseleksi. Pembobotan yang dilakukan pada indeks ini adalah dengan pemberian nilai bobot yang berbedapada komponen, indikator dan sub-indikator. Agregasi atau penggabungan indeks dilakukan dengan menggunakan metode aritmatik, sedangkan untuk interpretasi indeks dibuat dalam 5 kategori dengan skala 0-100.

\section{DAFTAR RUJUKAN}

Brown, R. M., McClelland, N. I., Deininger, R. A., dan Tozer, R. G. (1970). A WATER QUALITY INDEX- DO WE DARE.

Dewi, B. M. K. (2017). Perencanaan Pengembangan Bank Sampah Resik PD Kebersihan Menjadi Bank Sampah Skala Kota. (S-1), Institut Teknologi Nasional, Bandung.

Elsadig, H., Yassin, D. K. E. E., dan Elseory, D. M. (2016). Development of Composite Performance Index for Solid Waste Management. IOSR Journal of Environmental Science, Toxicology and Food Technology, 10(4), 83-90. doi:10.9790/2402-1004018390

Fatimah, F. N. a. D. (2016). Panduan Menyusun Key Performance Indikator. Yogyakarta: Quadrant.

Juwana, I. (2012). Development of a Water Sustainability Index for West Java, Indonesia. (Doctor of Philosophy), Victoria University, Australia.

Nardo, Saisana, Saltelli, Tarantola, Hoffman, dan Giovannini. (2005). Handbook on constructing composite indicators: methodology and user guide (Vol. Vol. 2005). Ispra, Italy: OECD Statistics Working Paper.

Nugraha, N. R. (2017). Evaluasi Pengelolaan Sampah di Wilayah Bantaran Sungai Kota Bandung "Studi Kasus Kelurahan Cikutra". (S-1), Universitas Pasundan, Bandung.

PD Kebersihan Kota Bandung. (2017). Data Timbulan Sampah Kota Bandung. Perusahan Daerah Kebersihan Kota Bandung. Bandung.

Peraturan Menteri Lingkungan Hidup Republik Indonesia No. 6. Tahun 2014. Pedoman Pelaksanaan Adipura. Indonesia.

Peraturan Menteri Pekerjaan Umum No. 3. Tahun 2013. Penyelenggaraan Prasarana dan Sarana Persampahan dalam Penanganan Sampah Rumah Tangga dan Sampah Sejenis Sampah Rumah Tangga. Indonesia.

Peraturan Pemerintah No. 81 Tahun 2012. Pengelolaan Sampah Rumah Tangga dan Sampah Sejenis Rumah Tangga. Indonesia.

Saffran, K., Cash, K., Hallard, K., Neary, B., dan Wright, C. (2001). CCME water quality index 1.0 user's manual. Canadian water quality guidelines for the protection of aquatic life, Canadian environmental quality guidelines. Canadian Council of Ministers of the Environment.

UNEP. (2005). INTEGRATED WASTE MANAGEMENT SCOREBOARD : A tool to measure performance in municipal solid waste management.

Wang, T.-C., dan Lee, H.-D. (2009). Developing a fuzzy TOPSIS approach based on subjective weights and objective weights. Expert systems with applications, 36(5), 89808985. 